\title{
TUGU PERJUANGAN PEMUDA DI DESA CELUKANBAWANG, GEROKGAK, BULELENG, BALI SEBAGAI MEDIA PENANAMAN NILAI NASIONALISME PADA SISWA SMA/MA
}

\author{
Ali Rausan Fikri
}

MAN 1 Bima, Nusa Tenggara Barat

e-mail fikrigagah100@gmail.com,

\begin{abstract}
Abstrak
Penelitian ini bertujuan untuk mengetahui; 1) faktor Tugu Perjuangan Pemuda di Desa Celukanbawang dapat dijadikan media penanaman nilai nasionalisme; 2) cara memanfaatkan Tugu Perjuangan Pemuda di Desa Celukanbawang sebagai media penanaman nilai nasionalisme pada siswa SMA/MA. Penelitian ini merupakan penelitian kualitatif dengan tahap-tahap yang dilakukan dalam penelitian adalah 1) rancangan penelitian, 2) teknik penentuan lokasi penelitian, 3) teknik penentuan informan, 4) teknik pengumpulan data, 5) teknik validasi, dan 6) teknik analisis data. Berdasarkan wawancara, observasi, studi pustaka atau dokumen di lapangan diketahui bahwa, 1) faktor Tugu Perjuangan Pemuda dapat dijadikan sebagai media penanaman nilai nasionalisme adalah ada dua faktor, yakni faktor nilai dan fungsi yang terkandung pada Tugu Perjuangan Pemuda. Nilainilai yang terkandung adalah nilai patriotisme, nilai persatuan dan kesatuan, dan nilai pendidikan. Sedangkan fungsinya adalah fungsi edukatif dan fungsi inspiratif. 2) cara atau strategi memanfaatkan Tugu Perjuangan Pemuda sebagai media penanaman nilai nasionalisme pada siswa SMA/MA adalah dengan menjadikan Tugu Perjuangan Pemuda sebagai sumber dan media dalam pembelajaran sejarah.
\end{abstract}

\section{Kata Kunci: Tugu, Media Penanaman Nilai Nasionalisme}

\begin{abstract}
This study aims to determine; 1) the factor of the Monument of Youth Struggle in the village of Celukanbawang can be used as a medium for the cultivation of the value of nationalism;2) how to exploit the Monument of Youth Struggle in Celukanbawang Village as a medium of nationalism value for high school / MA students. This research is a qualitative research with stages done in the research are 1) research design, 2) research location determination technique, 3) informant determination technique, 4) data collection techniques, through observation, interview, and literature study, 5) validation techniques, and 6) data analysis techniques. Based on interviews, observation, literature study or document in the field, it is known that 1) the factor of Monument of Youth Struggle can be used as media of nationalism value is two factors, namely value and function factor contained in Monument of Youth Struggle. The values contained are the values of patriotism, the value of unity and unity, and the value of education. While its function is an educative function and inspirational function. 2) the way or strategy to utilize Monument of Youth Struggle as media of nationalism value planting at SMA / MA students is by making Monument of Youth Struggle as source and media in learning history.
\end{abstract}

\section{Key Words: Monumen, Media Planting Value Nationalism}




\section{Pendahuluan}

Sejarah adalah suatu ilmu pengetahuan tentang rangkaian kejadian yang berkausalitas pada masyarakat manusia dengan segala aspeknya serta proses gerak perkembangannya yang kontinu dari awal sejarah hingga saat kini yang berguna bagi pedoman kehidupan masyarakat masa sekarang serta arah citacita masa depan (Sjamsuddin, 1996: 10). Sejarah mencatat bahwa pada tanggal 17 Agustus 1945 merupakan proklamasi kemerdekaan Indonesia, peristiwa proklamasi merupakan peristiwa yang sangat penting dan memiliki makna yang sangat mendalam bagi bangsa Indonesia. Dengan proklamasi kemerdekaan tersebut, maka bangsa Indonesia telah lahir sebagai bangsa dan negara yang merdeka.

Kemerdekaan Indonesia yang diproklamirkan oleh Bung Karno dan Bung Hatta atas nama bangsa Indonesia adalah Negara Republik Kesatuan, yaitu satu tanah air, satu bangsa dan satu bahasa (Saputera, 2007: 41). Proklamasi kemerdekaan Indonesia, jika dilihat dari sudut hukum merupakan pernyataan yang berisi keputusan bangsa Indonesia untuk menetapkan tatanan hukum nasional (Indonesia) dan menghapuskan tatanan hukum kolonial. Sedangkan, jika dilihat dari sudut politik ideologis merupakan pernyataan bangsa Indonesia yang lepas dari penjajahan dan membentuk Negara Republik Indonesia yang bebas, merdeka, dan berdaulat penuh (Arta \& Margi, 2014: 14-15). Proklamasi kemerdekaan tidak membuat Indonesia terlepas dari pengaruh bangsa asing, karena setelah kemerdekaan tersebut bangsa Indonesia dituntut untuk bisa mempertahankan kemerdekaannya dari bangsa asing yang ingin kembali menegakkan kekuasaannya di Indonesia.

Perjuangan yang dilakukan bangsa Indonesia diawal kemerdekaan untuk mempertahan kemerdekaan tidak hanya melalui perundingan melainkan bentuk perlawanan secara fisik yang sering dikenal dengan revolusi fisik. Masa revolusi fisik masyarakat lebih bersatu dari sebelumnya, yang sebelumnya kurang bersatu karena dipengaruhi oleh sistem perhubungan yang buruk, perpecahan-perpecahan internal, lemahnya kepemimpinan pusat, dan perbedaan kesukuan (Ricklefs, 1991: 318). Selama mempertahankan kemerdekaan pada masa revolusi fisik (1945-1950), Indonesia berada dalam kondisi yang rawan peperangan atau kondisi darurat perang di berbagai daerah di Indonesia, salah satunya usaha mempertahankan kemerdekaan yang dilakukan oleh masyarakat di Bali. Perlawanan yang dilakukan oleh masyarakat Bali melawan tentara asing akan terus diingat sampai seterusnya, untuk mengenang perlawanan tersebut pemerintah sudah banyak mendirikan tugu perjuangan atau monumen perjuangan di lokasi-lokasi tempat perjuangan tersebut, yang nantinya menjadi bahan pembelajaran bagi generasi selanjutnya. Tugu-tugu perjuangan dapat dijadikan sebagai media pembelajaran sejarah dan juga dapat dijadikan media penanaman nilai nasionalisme.

Nasionalisme adalah suatu sikap politik dari masyarakat suatu bangsa yang mempunyai kesamaan kebudayaan, dan wilayah serta kesamaan cita-cita dan tujuan, dengan demikian masyarakat suatu bangsa tersebut merasakan adanya 
kesetiaan yang mendalam terhadap bangsa itu sendiri (Zaidan, 2005: 30). Di era global sekarang ini khususnya di Indonesia nilai nasionalisme mengalami penurunan, banyak orang yang sudah lupa akan bangsanya sendiri. Contohnya paling sederhana banyak tidak hafal dengan ideologi bangsa kita yakni Pancasila, lupa akan hari-hari bersejarah, tidak peduli dengan peninggalan-peninggalan sejarah yang ada dan masih banyak yang lainnya.

Untuk mengatasi masalah menurun nilai nasionalisme di kalangan masyarakat Indonesia, khususnya para generasi muda saat ini. Maka perlu adanya sebuah sarana untuk bisa mengatasi masalah nasionalisme, dan sarana tersebut pastinya adalah melalui pendidikan. Pendidikan adalah alat untuk mengangkat derajat dan kualitas bangsa, manajemen yang baik dibutuhkan guna kelangsungan proses pendidikan. Manajemen pendidikan berbasis karakter adalah salah satu cara dan harus dilaksanakan. Kesadaran ini harus ditanamkan sedalam mungkin ke dalam jiwa masyarakat, dan tentunya melalui jalur pendidikan. Di titik inilah, pendidikan berbasis karakter bangsa adalah alat paling ampuh dalam rangka menanamkan kesadaran kebangsaan (Zusnani, 2012: 10).

Dalam proses pembelajaran selain menggunakan buku-buku dan penjelasan guru, juga diperlukan adanya sebuah media yang bisa dimanfaatkan untuk menanamkan nilai nasionalisme itu sendiri, banyak sekali media-media yang bisa digunakan, dan salah satunya adalah monumen (tugu) perjuangan. Tugu-tugu perjuangan mengandung nilai-nilai sejarah yang dapat menanamkan nilai nasionalisme bagi kalangan generasi muda. Di Bali banyak sekali tugu atau monumen yang dibuat pemerintah untuk mengenang perlawanan yang dilakukan oleh masyarakat Bali diantaranya Monumen Perjuangan Margarana di Tabanan, Monumen Tri Yuda Sakti di Sukasada, Monumen perjuangan di Pelabuhan Buleleng, Monumen Bhuawana Kerta, dan masih banyak yang lainnya. Salah satu tugu yang ada di Kabupaten Buleleng adalah Tugu Perjuangan Pemuda. Tugu Perjuangan Pemuda yang terletak di Desa Celukanbawang Kecamatan Gerokgak Kabupaten Buleleng. Tugu Perjuangan Pemuda ini dibangun tidak terlepas dari peristiwa penting yang pernah terjadi di desa Celukanbawang pada masa mempertahankan kemerdekaan.

Tugu Perjuangan Pemuda di Desa Celukanbawang bisa dijadikan sebagai sumber belajar sejarah dan sekaligus memiliki peran yang sangat penting untuk mewariskan nilai-nilai perjuangan yang terkandung di tugu tersebut kepada generasi muda sekarang ini untuk meningkatkan rasa nasionalisme di kalangan pemuda. Jika dikaitkan dengan pembelajaran sejarah di sekolah Tugu Perjuangan Pemuda ini sangat sesuai dijadikan sebagai sumber belajar sejarah sekaligus dijadikan sebagai media penanaman nilai nasionalisme pada kurikulum 2013 khususnya di SMA/MA. Peristiwa yang ada pada tugu tersebut bisa diterapkan pada materi usaha mempertahankan kemerdekaan di kelas XI semester genap dengan KD (Kompetensi Dasar) Menganalisis strategi dan bentuk perjuangan bangsa Indonesia dalam upaya mempertahankan kemerdekaan dari ancaman Sekutu dan Belanda. 
Rumusan masalah 1) Mengapa Tugu Perjuangan Pemuda di Desa Celukanbawang dapat dijadikan media penanaman nilai nasionalisme?, 2) Bagaimana cara memanfaatkan Tugu Perjuangan Pemuda di Desa Celukanbawang sebagai media penanaman nilai nasionalisme pada siswa SMA/MA?

Tujuan (1) mengetahui faktor-faktor Tugu Perjuangan Pemuda dapat dijadikan sebagai media penanaman nilai nasionalisme, dan (2) mengetahui strategi atau cara menjadikan Tugu Perjuangan Pemuda sebagai media penanaman nilai nasionalisme pada siswa SMA/MA.

\section{Metode}

Penelitian ini merupakan penelitian kualitatif dengan tahap-tahap yang dilakukan dalam penelitian ini adalah 1) rancangan penelitian, 2) teknik penentuan lokasi penelitian, penelitian ini terletak di Tugu Perjuangan Pemuda di Desa Celukanbawang, Kecamatan Gerokgak, Kabupaten Buleleng 3) teknik penentuan informan, penentuan informan dalam penelitian ini yaitu purposive sampling dan yang menjadi informan utama adalah Datuk Sanusi selaku veteran perjuangan di Desa Celukanbawang, 4) teknik pengumpulan data, melalui observasi, wawancara, dan studi pustaka atau dokumen, 5) teknik validasi dengan triangulasi data dan triangulasi metode, dan 6) teknik analisis data.

\section{Hasil dan Pembahasan}

Berdasarkan hasil observasi, wawancara, dan studi pustaka atau dokumen, maka dapat diperoleh tentang faktor-faktor Tugu Perjuangan Pemuda di Desa Celukanbawang dapat dijadikan sebagai media penanaman nilai nasionalisme, dan strategi atau cara Tugu Perjuangan Pemuda di Desa Celukanbawang dapat dijadikan media penanaman nilai nasionalisme pada siswa SMA/MA, yakni sebagai berikut.

\section{Latar Belakang Pendirian Tugu}

Pembangunan tugu tentu dilatarbelakangi beberapa faktor seperti faktor historis, faktor sosial, faktor budaya maupun faktor politik. Faktor historis yang melatarbelakangi pembuatan Tugu Perjuangan Pemuda adalah pertempuran dalam mempertahankan kemerdekaan banyak terjadi di Bali Utara, salah satunya berada di Desa Celukanbawang, pertempuran ini melibatkan pasukan Belanda dan para pemuda yang dibantu pasukan yang datang dari Banyuwangi. Pertempuran ini terjadi pada bulan September tahun 1947. Pertempuran yang terjadi merupakan bagian sejarah perjuangan dalam usaha mempertahankan kemerdekaan. Peristiwa pertempuran yang terjadi disebabkan karena kematian dari mata-mata Belanda yang berusaha untuk mendapatkan salah satu wanita desa pada waktu itu, yang mendapat penolakan dari para pemuda, pada pertempuran tersebut pemuda melaukan penyergapan terhadap pasukan Belanda. Dengan adanya penyergapan tersebut, menyebabkan kekalahan pada pihak Belanda. Pertempuran di Celukanbawang ini bukanlah titik akhir dari pertempuran pada waktu itu, tetapi kemudian berlanjut lagi ke Tegalamben pada bulan Oktober 1947. 
Setelah peristiwa revolusi fisik di Desa Celukanbawang berlalu, kenangan dari kisah para pejuang dalam usahanya mempertahankan kemerdekaan masih ada di benak masyarakat serta kisah heroik perjuangan di Desa Celukanbawang masih tercatat kuat dalam memori dari para pejuang yang masih hidup. Sejarah perjuangan para pahlawan telah memberikan inspirasi serta nilai-nilai lugur bagi generasi muda sekarang ini. Untuk tetap mengenang, menghargai, dan menghormati para pejuangan maka dimunculkan suatu ide atau gagasan untuk mendirikan sebuah Tugu Perjuangan, yang menjadi bukti sejarah perjuangan dari pemuda di Desa Celukanbawang.

Pendirian Tugu Perjuangan Pemuda di Desa Celukanbawang tidak terlepas dari faktor sosial yang ada, dengan tujuan sebagai sarana dalam pendidikan untuk mewariskan nilai-nilai dari perjuangan dan cinta tanah air. Pendirian sebuah tugu juga tidak lepas dari budaya yang berkembang di masyarakat, dimana bangunan tugu menjadi sebuah identitas wilayah dan merupakan kebanggan dari masyarakat setempat, karena di lingkungan tempat tinggalnya pernah terjadi peristiwa penting yang merupakan bagian dari sejarah perjuangan dalam usaha mempertahankan kemerdekaan Indonesia. Sementara itu faktor politik yang memengaruhi pendirian Tugu Perjuangan Pemuda adalah adanya keinginan dari pemerintah untuk mengabadikan peristiwa-peristiwa bersejarah dalam memperjuangkan tanah air Republik Indonesia. Dimana pemerintah memberikan bantuan-bantuan untuk pembangunan sebuah tugu.
Tugu Perjuangan Pemuda memiliki bentuk yang sederhana yang menggambarkan semangat dari perjuagan para pemuda. Area tugu ini dikelilingi oleh batas-batas berupa pagar, dan tugu tersebut memiliki fondasi dalam bentuk yang sederhana serta ada rantai besi yang mengeliling tugu, berada di bagian luar setiap fondasi dari tugu. Tugu ini juga memiliki simbol-simbol yankni ada simbol bintang dan juga simbol senjata. Simbolsimbol yang ada pada tugu ini, yakni simbol bintang merupakan cerminan dari para pemuda yang telah berjuang dan simbol senjata berupa senapan dan bambu runcing merupakan penggambaran dari senjata yang digunakan untuk berjuang pada waktu itu.

Area Tugu Perjuangan Pemuda saat sekarang ini menjadi tempat upacara bendera setiap tanggal 17 Agustus untuk mengenang peristiwa yang pernah terjadi di tempat tersebut dan menghargai jasajasa dari para pemuda yang telah berjuang.

\section{Tugu Perjuangan Pemuda Sebagai Media Penanaman Nilai Nasionalisme}

Tugu atau monumen pada umumnya memiliki makna sejarah yang sangat penting, yang bisa dijadikan sebagai media dalam menanamkan nilai nasionalisme. Begitupun halnya dengan Tugu Perjuangan Pemuda yang ada di Desa Celukanbawang, yang dibangun dengan tujuan untuk mengenang jasa pahlawan dan untuk bisa dijadikan sebagai sarana refleksi bagi para generasi muda mengenai perjuangan para pahlawan dalam memperjuangkan tanah airnya. Tugu Perjuangan Pemuda bisa 
dijadikan media dalam menanamkan nilai nasionalisme, karena memiliki nilai-nilai penting yang terkandung di dalamnya dan fungsi dari tugu itu sendiri.

\section{a. Nilai-Nilai Tugu Perjuangan Pemuda}

Tugu Perjuangan Pemuda yang ada di Desa Celukanbawang memiliki nilai-nilai yang sangat penting untuk dipahami oleh masyarakat, terutama oleh generasi muda dalam meningkatkan kesadaran nasionalisme. Adapun nilai-nilai yang terkandung dalam Tugu Perjuangan Pemuda adalah nilai patriotisme, nilai persatuan dan kesatuan, serta nilai pendidikan.

a) Nilai Patriotisme

Patriotisme berasal dari kata patria, artinya tanah air. Kata patria berubah menjadi patriot yang berarti seseorang yang mencintai tanah air. Seorang patriotic adalah orang yang cinta pada tanah air dan rela berkorban untuk mempertahankan negaranya. Patriotisme berarti paham tentang kecintaan pada tanah air. Nilai patriotisme juga tercermin dalam bangunan Tugu Perjuangan Pemuda, hal ini dapat dilihat dari para pejuang dalam usaha menjaga tanah kelahiran dari serangan musuh yang hendak mengganggu ketenteraman rakyat khususnya di Bali dan di Indonesia pada umumnya. Semangat perjuangan ini pada sikap pantang menyerah para pejuangan yang rela mengorbankan jiwa dan raga demi rakyat serta tanah kelahiran tercinta.

Nilai patriotisme yang terwujud dari semangat para pejuang dalam melawan musuh, baik sebelum kemerdekaan maupun saat mempertahankan kemerdekaan, sudah seharusnya menjadi bahan pembelajaran bagi generasi muda dalam meningkat rasa nasionalisme, tentu caranya tidak harus sama dengan para pejuang karena kondisinya sudah berbeda, tapi yang perlu diambil adalah semangat dari para pejuang tersebut. Wujudnya bisa dalam bentuk menjaga peninggalan- peninggalan sejarah, melestarikan tradisi atau budaya di sekitar, dan menjaga kelestarian lingkungan sebagai wujud cinta tanah air. Bangunan tugu perjuangan sudah sepantasnya bisa dimanfaatkan sebagai sarana refleksi bagi generasi muda mengenai semangat juang dari para pahlawan dalam mempertahankan tanah airnya.

b) Nilai Persatuan dan Kesatuan Persatuan berasal dari kata satu yang berarti utuh atau tidak terpecah-belah. Makna persatuan dan kesatuan bangsa dapat mewujudkan sifat kekeluargaan, jiwa gotong royong, musyawarah dan lain sebagainya. Jika dikaitkan dengan yang ada pada masa mempertahankan kemerdekaan, wujud rasa persatuan dan kesatuan dari pejuang adalah mereka bersatu padu, mengorbankan apapun yang mereka miliki, dengan kekuatan bersama untuk mempertahankan kemerdekaan.

Persatuan dan kesatuan menjadi landasan bagi bangsa Indonesia, makna persatuan yang tertuang dalam sila ketiga pada Pancasila adalah menjadi modal untuk tetap menjaga Kebhinekaan bangsa Indonesia. Hendaknya rasa persatuan dan kesatuan tersebut dapat kita pelajari dari yang sudah diajarkan oleh para pahlawan dalam berjuang melawan musuh. Pada bangunan tugu dapat memberikan pembelajaran mengenai nilai persatuan 
maupun kesataun. Tentunya ini harus dimanfaatkan untuk membangun rasa nasionalisme pada masyarakat khususnya para generasi muda, untuk menciptakan keutuhan bangsa dan mencegah terjadinya perpecahan yang sedang banyak terjadi sekarang ini.

c) Nilai Pendidikan

Tugu Perjuangan Pemuda tidak hanya sebagai simbol perjuangan, tetapi juga mengandung nilai-nilai pendidikan yang dapat dilihat dari sudut historis. Nilai historis yang dapat dipetik dari Tugu Perjuangan Pemuda adalah pengalaman masa lampau mengenai perjuangan para pejuang dalam mempertahankan kemerdekaan Indonesia dari kekuatan asing. Peristiwa pertempuran yang pernah terjadi hendaknya menjadi pelajaran dan motivasi bagi generasi muda untuk tetap semangat berjuang, yang dulu para pejuang semangat berjuang demi mempertahankan kemerdekaan dan sekarang generasi muda harus semangat berjuang untuk mengisi kemerdekaan dengan meningkatkan pendidikan dan melawan kolonialisme baru di zaman globalisasi ini.

Bangunan tugu sudah seharusnya dijadikan sebagai bahan untuk pembelajaran, terutama pembelajaran sejarah. Nilai-nilai yang terkandung dalam tugu tersebut dapat membentuk karakter peserta didik, dan menumbuhkan kesadaran nasionalisme. Dengan menjadikan tugu sebagai media dalam mengajarkan nilainilai perjuangan dan dalam upaya menumbuhkan kesadaran nasionalisme, maka akan dapat dengan cepat mencapai tujuan dari pembelajaran, karena bangunan tugu tersebut mengandung nilai-nilai perjuangan dari para pahlawan dalam mempertahankan kemerdekaan Indonesia.

Simbol bintang yang menjadi penanda dari para pemuda yang berjuang pada waktu itu, harus bisa dimaknai dengan baik. Dimana simbol bintang tersebut menunjukkan pentingnya perjuangan para pemuda, harus dimaknai jiwa atau semangat pantang menyerah yang ditunjukkan oleh para pemuda dalam berjuang mempertahankan kemerdekaan. Dengan memaknai nilai-nilai yang terkandung tersebut, maka jiwa nasionalisme pada generasi muda dapat terwujud dan penghargaan terhadap jasa- jasa para pahlawan terdahulu akan terwujud pula.

\section{b. Fungsi Tugu Perjuangan Pemuda}

Sama halnya dengan tugu-tugu yang telah dibangun di Indonesia atau di Bali khususnya, yakni untuk mengenang jasa pahlawan dan sebagai penanda bahwa di tempat tersebut pernah terjadi sutu peristiwa penting. Begitupun juga dengan Tugu Perjuangan Pemuda di Desa Celukanbawang. Banyaknya nilai-nilai yang penting dalam Tugu Perjuangan Pemuda, menjadikan tugu ini bisa digunakan sebagai tempat belajar, sebagai sarana refleksi untuk membentuk karakter, terutama masalah kesadaran nasionalisme yang mengalami penurunan. Tugu dapat dijadikan sebagai media dalam menanamkan nilai nasionalisme pada generasi muda sekarang ini. Tugu memiliki fungsi, yakni fungsi edukatif dan fungsi inspiratif. Hal inilah yang akan menjadikan tugu sebagai media yang tepat untuk bisa menanamkan nilai nasionalisme pada generasi muda, 
khususnya para pelajar.

a) Fungsi Edukatif

Tugu berfungsi sebagai wahana pendidikan, sarana membagi pengetahuan (baik baru maupun lama), dan juga tempat untuk melakukan studi. Dalam hal ini, monumen dituntut tidak hanya sebagai sarana pembelajaran publik, namun juga harus mampu menyokong perkembangan ilmu pengetahuan selayaknya pusat studi atau pusat kajian di sekolah (Widja, 1988: 49). Tugu Perjuangan Pemuda yang dibangung sarat akan nilai-nilai perjuangan. Nilai-nilai tersebut hendaknya diwariskan kepada peserta didik melalui pendidikan, yang diaplikasikan dalam pembelajaran di kelas. Banyak nilai-nilai perjuangan yang terkandung, menjadikan Tugu Perjuangan Pemuda ini bisa dikembangkan sebagai media dalam menanamkan nilai nasionalisme pada siswa.

Dengan memanfaatkan Tugu Perjuangan Pemuda sebagai sarana edukatif akan membuat tugu tersebut tidak hanya dipandang sebagai sebuah bangunan yang mengingatkan kita terhadap peristiwa yang terjadi di masa lalu. Namun juga dapat memberikan refleksi bagaimana menghargai perjuangan pahlawan kita, dan membuat kita berfikir dan bersikap dengan bijaksana dalam menikmati hasil dari perjuangan para pahlawan. Instansi pendidikan yakni sekolah dan juga tenaga pengajar harus punya kesadaran untuk memanfaatkan sumber belajar yang ada di sekitarnya, mamanfaatkan media yang konkrit seperti bangunan tugu akan lebih mempermudah dalam menyampaikan materi pembelajaran b) Fungsi Inspiratif

Berbagai kisah sejarah dapat memberikan inspirasi pada para pembaca dan pendengarnya. Dengan belajar sejarah kita akan memperoleh ide-ide atau konsepkonsep baru yang kreatif serta berguna bagi pemecahan masalah masa kini, juga penting untuk memperoleh inspirasi dan semngat bagi mewujudkan identitas sebagai suatu bangsa, semangat nasionalisme maupun dalam upaya menumbuhkan harga diri bangsa (Widja, 1988: 50). Dalam konsep pembangunan monumen (tugu) fungsi inspiratif dapat memberikan inspirasi dan semangat untuk mewujudkan identitas sebagai suatu bangsa, di samping mengambil ide-ide maupun konsep yang berguna yang terkandung dalam pembangunan sebuah monumen (Latief, 2006: 72).

Tugu Perjuangan Pemuda bisa menjadi inspirasi bagi masyarakat, terutama anak muda, yakni para pelajar. Semangat juang yang ditunjukan oleh para pejuangan yang dikisahkan dalam bangunan Tugu Perjuangan Pemuda ini bisa menjadi inspirasi. Semangat perjuangan dan berani berkorban yang ditunjukkan oleh para pejuangan yang dikisahkan dalam bangunan tugu, dapat membentuk karakter pada siswa khususnya. Karakter akan mereka cinta terhadap tanah air, merawat yang ada di tempat mereka, dan menghargai apa yang dimiliki bangsanya sendiri. Kesadaran nasionalisme akan terbentuk dengan mengambil inspirasi dari tokoh-tokoh pahlawan yang dikisahkan dalam bangunan tugu. Untuk itu Tugu Perjuangan Pemuda harus dimanfaatkan 
sebagai media dalam menanamkan nilai nasionalisme.

\section{Strategi Pemanfaatan Tugu}

Sejarah adalah mata pelajaran yang menanamkan pengetahuan, sikap, dan nilai-nilai mengenai proses perubahan dan perkembangan masyarakat Indonesia dan dunia dari masa lampau hingga masa kini. Pengajaran sejarah di sekolah bertujuan agar siswa memperoleh kemampuan berpikir historis dan pemahaman sejarah. Melalui pengajaran sejarah, siswa mampu mengembangkan kompetensi untuk berpikir secara kronologis dan memiliki pengetahuan tentang masa lampau yang dapat digunakan untuk memahami dan menjelaskan proses perkembangan dan perubahan masyarakat serta keragaman sosial budaya dalam rangka menemukan dan menumbuhkan jati diri bangsa di tengah-tengah kehidupan masyarakat dunia. Sedangkan fungsi pembelajaran sejarah adalah untuk menyadarkan siswa akan adanya peroses perubahan dan perkembangan masyarakat dalam dimensi waktu dan untuk membangun perspektif serta kesadaran sejarah dalam menemukan, memahami, dan menjelaskan jati diri bangsa di masa lalu, masa kini, dan masa depan di tengah-tengah perubahan dunia (Agung, 2013: 55-56).

Realitas yang selama ini terjadi, para pendidik hanya berkonsentrasi pada materi tanpa mempertimbangkan bagaimana proses tersebut mempengaruhi peserta didik dan membentuk lingkungan pembelajaran. Sistem umpan balik yang efektif bermaksud menjembatani gap yang ada antara pendidik dan peserta didik dalam proses pembelajaran (Aman, 2011: 67). Apabila sejarah hendak tetap berfungsi dalam pendidikan, maka harus dapat menyesuaikan diri dengan situasi sosial dewasa ini. Jika studi sejarah terbatas pada pengetahuan fakta-fakta, akan menjadi steril dan mematikan segala minat terhadap sejarah (Kartodirdjo, 1982: 86). Oleh karena itu, perlu adanya inovasi atau perubahan dalam pengajaran sejarah, mulai dari penyusunan silabus dan RPP, pendekatan, strategi dan metode-metode dalam pengajaran sejarah, serta penggunaan media yang menarik.

Untuk mencapai tujuan dari pembelajaran diperlukan pendekatan, strategi dan metode. Adapun pendekatan pembelajaran dapat diartikan sebagai titik tolak atau sudut pandang kita terhadap proses pembelajaran, yang merujuk pada pandangan tentang terjadinya suatu proses yang sifatnya masih sangat umum, di dalamnya mewadahi, menginspirasi, menguatkan, dan melatari metode pembelajaran dengan cakupan tertentu, sementara strategi pembelajaran terkandung makna perencanaan. Artinya, bahwa strategi pada dasarnya masih bersifat konseptual tentang keputusankeputusan yang akan diambil dalam suatu pelaksanaan pembelajaran Dan metode mengajar merupakan bagian dari strategi pembelajaran yang merupakan langkahlangkah taktis yang perlu diambil guru dalam menunjang strategi yang hendak dikembangkan (Aman, 2011: 112). Banyak sekali metode pembelajaran yang bisa digunakan, salah satunya adalah metode belajar di luar kelas dan sosio-drama.

Peran sejarah yang begitu vital 
dalam membangun karakter siswa dan menumbuhkan kesadaran nasionalisme, maka pembelajaran sejarah harus bisa menarik minat dari siswa. Media pembelajaran yang menarik sangat diperlukan dalam pembelajaran, ada banyak media yang bisa digunakan dalam pembelajaran sejarah, salah satunya yaitu tugu. Selain bisa menjadi media dalam pembelajaran, tugu juga bisa difungsikan sebagai sumber belajar bagi siswa. Dengan menggunakan tugu sebagai media dan mengajak siswa untuk belajar di luar kelas akan membuat pembelajaran yang menarik dan menyenangkan bagi siswa.

Dengan pembelajaran di luar kelas media yang digunakan akan konkrit. Seperti yang sudah dijelaskan sebelumnya tentunya untuk bisa melaksanakan hal tersebut diperlukan inovasi baik dalam hal pendekatan, strategi dan metode pembelajaran. Penggunaan Tugu Perjuangan Pemuda sebagai media dalam pembelajaran, untuk meningkatkan kesadaran nasionalisme siswa bisa diterapkan pada KD (Kompetensi Dasar) Menganalisis strategi dan bentuk perjuangan bangsa Indonesia dalam upaya mempertahankan kemerdekaan dari ancaman Sekutu dan Belanda, tepatnya di kelas XI pada semester genap.

Penggunaan metode pembelajaran di luar kelas dengan Tugu Perjuangan Pemuda sebagai medianya memiliki kelebihan-kelebihan tertentu, yakni mendorong motivasi belajar, suasana belajar yang menyenangkan, mengasah kreativitas, meningkatkan keterampilan sosial, penggunaan media yang konkret, dan yang lainnya (Vera, 2012: 28). Untuk itu guru harus menyususn sebuah perencanaan untuk bisa melaksanakan pembelajaran di luar kelas, salah satunya dengan penyusunan RPP (Rencana Pelaksanaan Pembelajaran).

Penggunaan metode mengajar di luar kelas harus menggunakan metodemetode tertentu, salah satunya adalah dengan menggunakan metode penugasan, dimana guru memberikan tugas kepada siswanya, dan siswanya mencari jawaban di luar kelas. Guru harus bisa menyusun langkah-langkah yang akan dilakukan dan dijelaskan ke siswanya dalm melakukan pembelajaran di luar kelas. Langkahlangkah tersebut harus jelas digambar dalam RPP (Rencana Pelaksanaan Pembelajaran). Selain metode belajar di luar kelas, tugu perjuangan juga dapat dijadikan sebagai media pada pembelajaran di dalam kelas.

Pembelajaran di dalam kelas dengan menggunakan media tugu, memerlukan metode-metode belajar tertentu, salah satunya dengan menggunakan metode sosio-drama. Metode ini mengembangkan kreativitas siswa, memupuk kerja sama antara siswa, menumbuhkan bakat siswa dalam seni drama, siswa lebih memperhatikan pelajaran karena menghayati sendiri, memupuk keberanian siswa di depan kelas, melatih siswa untuk menganalisa masalah dan mengambil kesimpulan dalam waktu singkat. Dengan membawa peristiwa yang terjadi di tugu tersebut ke dalam kelas, permainan peran dari siswa akan membuat suasana belajar lebih menyenangkan. Pembelajaran di dalam kelas yang menggunakan metode sosio-drama dan yang lainnya harus 
direncanakan dengan baik oleh guru.

Penggunaan Tugu Perjuangan Pemuda sebagai media penanaman nilai nasionalisme pada pembelajaran sejarah, akan menambah semangat semangat belajar atau motivasi belajar dari peserta didik, karena media yang digunakan merupakan media yang mengisahkan perjuangan dari pahlawan dalam mempertahankan kemerdekaan Indonesia. Langsung ke lapangan atau objek Tugu Perjuangan Pemuda akan membuat tujuan dari pembelajaran cepat tercapai dan dengan mengisahkan peristiwa peruangan dari para pahlawan dengan permainan peran akan membuat suasana belajar lebih menarik dan tentunya tujuan dari pembelajaran akan cepat tercapai. Pada penelitian ini, peneliti mencoba memberikan pemikiran berupa RPP dengan penggunaan metode belajar di luar kelas yang dilanjutkan ke pembelajaran di dalam kelas dengan penggunaan tugu sebagai medianya.

Penggunaan Tugu Perjuangan

Pemuda sebagai media pembelajaran sejarah diharapkan akan mampu meningkatkan kesadaran nasionalisme siswa yang saat ini mulai berkurang. Dengan menjadikan tugu sebagai media belajar di luar kelas maupun di dalam kelas, nantinya siswa akan dengan langsung mengamati bangunan tugu yang mengisahkan perjuangan dari pahlawan dalam mempertahankan kemerdekaan Indonesia.

\section{Simpulan dan Saran}

$\begin{array}{lcr}\text { Latar belakang pendirian } & \text { Tugu } \\ \text { Perjuangan } & \text { Pemuda di } & \text { Desa } \\ \text { Celukanbawang, tidak terlepas dari faktor }\end{array}$

historis, faktor sosial, faktor politik, dan faktor budaya. Peristiwa yang terjadi di tempat tersebut yakni, pertempuran yang melibatkan pasukan Belanda dan para pemuda yang dibantu pasukan yang datang dari Banyuwangi. Pertempuran ini terjadi pada tahun 1947. Berdasarkan dengan adanya peristiwa penting yang terjadi di lokasi tersebut, kemudian dengan bantuan pemerintah Kabupaten Buleleng, maka dibangun sebuah tugu, untuk mengenang peristiwa yang terjadi di tempat tersebut.

Adapun pembangunan tersebut dilaksanakan pada tahun 1966. Dengan harapan dapat menjadi sarana pembelajaran bagi generasi muda, dan menjadi identitas sekaligus kebanggaan bagi masyarakat.

Tugu Perjuangan Pemuda ini bisa dijadikan sebagai media dalam menanamkan nilai nasionalisme karena: Tugu ini mengandung nilai-nilai yang sangat penting, diantaranya adalah nilai patrotisme, nilai persatuan dan kesatuan, dan nilai pendidikan. Dan memiliki fungsi eduktif dan fungsi inspiratif. Tugu ini dapat dimanfaat dalam upaya menumbuhkan kesadaran nasionalisme, dengan menjadikan tugu sebagai sarana refleksi untuk mengenang peristiwa pertempuran yang terjadi dalam mempertahankan kemerdekaan dan refleksi mengenai semangat juang dari para pahlawan.

Dalam menumbuhkan kesadaran nasionalisme dikalangan peserta didik, Tugu Perjuangan Pemuda bisa dimanfaatkan sebagai media dalam pembelajaran sejarah, dengan melakukan 
inovasi dalam pembelajaran. Salah satunya dengan menggunakan metode belajar di luar kelas dengan langsung berkunjung ke tempat-tempat bersejarah maupun pembelajaran di dalam kelas dengan metode sosio drama. Dengan demikian akan menumbuhkan motivasi belajar siswa, dan apa yang menjadi tujuan pembelajaran akan bisa Cepat tercapai.

Adapun sarannya adalah bagi generasi muda dan para pelajar hendaknya dengan adanya tugu perjuangan ini dapat dijadikan sebagai sarana untuk merefleksi diri dengan melihat bagaimana perjuangan para pahlawan, dan bisa dijadikan motivasi dan inspirasi dalam melanjutkan perjuangan untuk mengisi kemerdekaan ke arah yang positif. Menumbuh kesadaran nasionalisme, dengan menjaga apa yang menjadi milik bangsa sendiri, menjaga lingkungan sekitarnya, dan menghargai apa yang sudah dilakukan oleh para pahlawan sebelumnya. Bagi guru keberadaan Tugu Perjuangan Pemuda yang dekat dengan lingkungan sekolah diharapkan dimanfaat sebagai media dan sumber dalam pembelajaran, dan diharapkan dapat membantu dalam meningkatkan kualitas pembelajaran dan memperkaya pengetahuan siswa tentang bukti-bukti peninggalan sejarah. Bagi masyarakat dan pemerintah, Tugu Perjuangan Pemuda merupakan bangunan yang patut dijaga dan dirawat, sebagai masyarakat seharusnya peduli dengan keberadaan dari Tugu Perjuangan Pemuda, cara dengan membersihkan areal di lingkungan tugu tersebut dan bagi pemerintah, harus ada kepedulian terhadap bangunan-bangunan sejarah yang memuat peristiwa penting perjalan bangsa Indonesia.

\section{Daftar Pustaka}

Aman. 2011. Model Evaluasi Pembelajaran Sejarah.

Yogyakarta: Ombak.

Arta, Ketut Sedana dan I Ketut Margi. 2014. Sejarah Indonesia dari Proklamasi Sampai Orde Reformasi. Singaraja: Universitas Pendidikan Ganesha Press \& Graha Ilmu.

Kartodirdjo, Sartono. 1982. Pemikiran dan Perkembangan Historiografi Indonesia: Suatu Alternatif. Jakarta: Gramedia Pustaka Utama.

Latief, Abdul. 2006. Manusia, Filsafat dan Sejarah. Jakarta: PT. Bumi Angkasa.

Ricklefs. 1991. Sejarah Indonesia Modren. Yogyakarta: Gajah Mada University Press

Saputera, I Gusti Bagus. 2007. Merdeka Melalui Diplomasi (Perjuangan Ide Anak Agung Gde Agung). Denpasar: Yayasan Usaha Pekerja.

Vera, Adelia. 2012. Metode Mengajar Anak di Luar Kelas (Outdoor Study). Yogyakarta: DIVA Press.

Widja, I Gde. 1988. Pengantar Ilmu Sejarah "Sejarah dalam Perspektif Pendidikan". Semarang: Satya Wacana. 